\title{
The effect of phosphorus doses on cotton growth under full and deficit irrigation conditions
}

\author{
Yusuf Ziya AYGÜN *1, Mehmet MERT ${ }^{1}$ \\ ORCID: 0000-0001-9842-006X; 0000-0002-0457-0532
}

${ }^{1}$ Hatay Mustafa Kemal University, Faculty of Agriculture, Department of Field Crops, 31060 Hatay, Turkey

\begin{abstract}
Water shortages and harmful effects of excessive fertilizer use are present in cotton production areas. This study was carried out in three replications in greenhouse conditions according to split plots in randomized parcels to examine some growth parameters (plant height, number of leaf, amount of chlorophyll, fresh weight and dry weight) of different phosphorus doses in cotton under full and restricted irrigation conditions. Flash cultivar of Gossypium hirsutum L. species was used as plant material. Phosphorus dose of 16, 24, 32 and $40 \mathrm{mg} \mathrm{kg}^{-1}$ was applied to the plants under $100 \%, 66 \%$ and $33 \%$ irrigation conditions. As a result, irrigation levels had a statistically significant effect on all parameters, whereas phosphorus doses had a statistically significant effect on all parameters except amount of chlorophyll. In terms of irrigation, it was determined that $33 \%$ water shortage did not cause significant decreases in plant height, number of leaves, chlorophyll amount, dry weight. In addition, it has been determined that irrigation levels are effective in phosphorus uptake and, water shortage conditions decrease the fresh and dry weights of cotton after P24 phosphorus level, and full irrigation conditions tend to increase these properties, albeit slightly.
\end{abstract}

Key words: cotton, restricted irrigation, phosphorus, drought stress, plant growth

\section{Tam ve kısıntılı sulama koşullarında fosfor dozlarının pamuk gelişimine etkisi}

\section{Özet}

Pamuk üretim alanlarında, su sıkıntısı ve aşırı gübre kullanımının zararlı etkileri söz konusudur. Bu çalışma, 2012 yılında, tam ve kısıntılı sulama koşullarında farklı fosfor dozlarının pamukta bazı gelişim parametrelerini (bitki boyu, yaprak sayısı, klorofil miktarı, yaş ağırlık ve kuru ağırlık) incelemek üzere tesadüf parsellerinde bölünmüş parseller deneme desenine göre sera koşullarında üç tekerrürlü yürütülmüştür. Bitki materyali olarak Gossypium hirsutum L. türüne ait Flash çeşidi kullanılmıştır. Bitkilere tam sulama ile \%66 ve \%33 su kısıtı koşullarında; 16, 24,32 ve $40 \mathrm{mg} \mathrm{kg}^{-1}$ dozlarda fosfor uygulanmıştır. Araştırma sonucunda, sulama düzeylerinin tüm parametreler, fosfor dozlarının ise klorofil miktarı hariç incelenen diğer parametreler üzerinde istatistiki önemli olduğu gözlemlenmiştir. Sulama yönünden hafif su kısıtının (\% 33) bitki boyu, yaprak sayısı, klorofil miktarı ve kuru ağırlıkta önemli oranda azalışlara neden olmadığı tespit edilmiştir. Ayrıca sulama düzeylerinin fosfor alımında etkili olduğu, su kısıtı koşullarının P24 fosfor düzeyinden sonra pamuğun yaş ve kuru ağırlıklarını azalttığı, tam sulama koşullarının ise bu özellikleri az da olsa artırma eğiliminde olduğu tespit edilmiştir.

Anahtar kelimeler: pamuk, kısıntılı sulama, fosfor, kuraklık stresi, bitki gelişimi

\section{Introduction}

Cotton is the most important fiber plant produced as a textile raw material source in the world. Cotton widely grown in the world between latitudes $37^{\circ}$ North and $35^{\circ}$ South; has been used in textiles and also the manufacture of a

\footnotetext{
${ }^{*}$ Corresponding author / Haberleşmeden sorumlu yazar: Tel.: +905455463632; Fax.: +905455463632; E-mail: yusufziyaaygun @ mku.edu.tr

(C) Copyright 2021 by Biological Diversity and Conservation $\quad$ Received: 18.09.2021; Published: 15.12.2021 BioDiCon. 1004-180921
} 
number of products such as fishing net, sewing thread, rope, twine, automobile interior upholstery, explosives, plastic and photographic film with its fiber [1]. In addition, it is an important raw material of the oil industry with its seeds and the feed industry with its pulp [2]. Nowadays, cotton, which is widely produced in the world and is among the most important agricultural products, with its wide usage area and the added value it provides, is expected to maintain its importance in future predictions. Therefore, it is necessary to understand the factors that will hinder sustainability in cotton production and perhaps put it in a bottleneck.

There are various biotic and abiotic stress factors in plants especially cotton that slow or stop growth and development $[1,3,4,5,6]$. One of the most important of these factors is water restriction. Cotton is very sensitive to soil moisture. In order to make an economical production, a suitable prepared irrigation program and adequate irrigation should be performed at appropriate intervals in cotton cultivation. Components such as the climate of the region, soil conditions of the production area, and root depth, appearance and growing stage of plants are factors that should be considered in irrigation programs [7]. Optimum irrigation is completely normal conditions; plants are irrigated in a way that there is no decrease in yield and irrigation water is applied to increase the amount of moisture in the soil up to the field capacity. In case of limited water supply; considering the water-yield relationships of the plants, restricted irrigation is required according to the growing periods in which the plants need water the most [8]. Water stress in plants occurs especially during these periods. Cotton is very sensitive to water shortage during germination, preflowering and post-boll stages [1]. In restricted irrigation, instead of reaching maximum yield in crop production, it is possible to reduce irrigation water by considering a slight decrease in yield. In this way, it is possible to irrigate more areas with the same amount of water and to get more income from unit water.

Considering the probable water scarcity for East Mediterranean and the whole world at the present time and especially in the future, more economical irrigation conditions have been forced. For this reason, researches on limited irrigation levels and different irrigation methods are carried out in order to keep yield loss in agricultural products to a minimum. Water restriction of around $30 \%$ does not cause a significant decrease in cotton yield [9]. In a study conducted at Nazilli Cotton Research Institute, two times irrigation at 30-day intervals between the beginning of flowering and the formation of the boll in Nazilli 84 cultivar resulted in $11 \%$ yield reduction compared to normal irrigation [10]. [11] reported that [12] obtained the highest yield by irrigating 3 times (6 weeks after planting + flowering + boll formation) for NIAB-78 cotton cultivar and 2 times (6 weeks after planting + flowering period) for NIAB-86 cultivar. If irrigation can be made only once, it should be at the beginning of flowering [10].

Fertilization plays an important role in the development and productivity of the cotton plant as well as economically benefiting from irrigation water. However, especially the harmful effects of excessive fertilization should be avoided. It has been observed in studies that nitrogen, phosphorus and potassium, which are fundamental fertilizers [13], increase cotton productivity by $20-50 \%$ [2]. However, chemical inputs used in agricultural fields causes a significant environmental and health troubles [14]. Soil and water pollution are at the forefront of these problems, and industrial wastes, pesticide use and rapid urbanization also cause it [15]. Phosphorus, one of the main nutrients, is the building block of the cell nucleus and plays a considerable role in cell division and the development of meristematic tissues, thus increasing the number of flowers and bolls [16]. In addition, phosphorus plays a vital role in photosynthesis and respiration and is important for plant nutrition in the pre-ripening period in cotton. As the plant matures, phosphorus is transported from the leaves to the bolls [2]. Seed cotton contains $0.60 \%$ phosphorus on average and $52-$ $62 \%$ of total phosphorus is accumulated in seeds. [17], observed that the amount of phosphorus in cotton with restricted irrigation varied between $0.15 \%$ and $0.22 \%$. Cotton takes advantage of the phosphorus in the soil solution depending on the moisture.

All over the world, there are harmful effects of water shortage and excessive fertilizer use. The aim of this study was to determine the phosphorus utilization of cotton plants to be grown under restricted irrigation conditions and the effect of this situation on plant growth.

\section{Material and method}

The experiment was laid out according to the split plots in randomized parcels under greenhouse conditions with three replications in 2012. Greenhouse was located in Hatay Mustafa Kemal University. During the growing period, cotton was grown in 36 pots of 40 liters with a diameter of $44 \mathrm{~cm}$ and a height of $36 \mathrm{~cm}$. Irrigation levels were placed in main plots and phosphorus levels were placed in sub plots. Flash cotton cultivar (Gossypium hirsutum L.) was used as the plant material. This early maturing, smooth leaf cultivar has broad adaptability to a wide range of soil types [18]. Cotton seeds were sown in pots in seedbed method in April 15. The test plots were irrigated when 60\% of the available moisture capacity was consumed in the soil. The irrigation levels used in the experiment were given below:

IL100: irrigation water requirement fulfilled

IL66: Slight water restriction, $66 \%$ of irrigation water fulfilled

IL33: Severe water restriction, $33 \%$ of irrigation water fulfilled

Irrigation times for all treatments was determined according to [19].

Triple super phosphate was used as a phosphorus source. Phosphorus doses were arranged to be 16, 24, 32 and $40 \mathrm{mg} \mathrm{kg}^{-1}$ (P16, P24, P32 and P40). Phosphorus treatments was applied at pre-sowing time. 
The soil material used in the experiment was taken from the first $30 \mathrm{~cm}$ layer of the land, one of the most common samples of the Amik Plain [20], by filling in sacks and brought to the laboratory. After the said soils were dried in room conditions, they were blended and filled with $10 \mathrm{~kg}$ for each pot. In addition, physical properties of soil such as field capacity, wilting point and bulk density were determined. Fertilizers needed by the plant were given to pot soil at once at the beginning of the trial. To determine the field capacity; 100 grams of air dry soil was taken into a 50 $\mathrm{ml}$ glass cylinder, and then $10 \mathrm{ml}$ of pure water was poured on it and closed so that it could not get air, and after 24 hours the amount of wetted soil was proportioned to the amount of dry soil. After calculating the field capacity, the wilting point was determined by proportionality over the field capacity value depending on the soil structure. Bulk density was calculated by the method of proportioning the air dry weights of the soils with a certain volume to the oven dry weights. The amount of chlorophyll was measured in the boll formation period, a few days before the harvest, with the chlorophyll meter separately from the lower and upper leaves. After boll formation, the plants were harvested $1 \mathrm{~cm}$ above the soil level. The cotton bolls were not waited to grow and mature, as main goal of this research was to examine overall biomass growth rather than fiber yield. Plant samples were harvested, washed with distilled water and dried in a drying cabinet at $65^{\circ} \mathrm{C}$ for 48 hours.

The results obtained from the study were evaluated in a computer program called IBM SPSS Statistics 24 [21] for statistical analysis and subjected to variance analysis. The means of the parameters were grouped by Tukey's multiple comparison test [22].

\section{Results}

The effect of different irrigation and phosphorus levels on plant height, leaf number and chlorophyll amount were given in Table 1. As a result of the research, the differences among the irrigation levels in terms of all three characteristics did not change according to the phosphorus doses. In other words, no interaction of irrigation levels $\mathrm{x}$ phosphorus doses was found (Table 1).

Table 1. Mean values for plant height, leaf number and chlorophyll content at different irrigation and phosphorus levels

\begin{tabular}{lccc}
\hline Irrigation Levels & $\begin{array}{c}\text { Plant Height } \\
(\mathrm{cm})\end{array}$ & $\begin{array}{c}\text { Leaf Number } \\
\text { (per plant) }\end{array}$ & $\begin{array}{c}\text { Chlorophyll Content } \\
(\mathrm{cci})\end{array}$ \\
\hline IL 33 & $78.00 \pm 1.50 \mathrm{~b}$ & $10.92 \pm 0.23 \mathrm{~b}$ & $45.75 \pm 0.59 \mathrm{~b}$ \\
IL 66 & $82.83 \pm 2.03 \mathrm{a}$ & $12.00 \pm 0.37 \mathrm{a}$ & $47.00 \pm 0.64 \mathrm{ab}$ \\
IL 100 & $85.75 \pm 2.13 \mathrm{a}$ & $12.42 \pm 0.31 \mathrm{a}$ & $49.17 \pm 0.46 \mathrm{a}$ \\
\hline P Levels & & & $46.22 \pm 0.81$ \\
P16 & $72.78 \pm 1.12 \mathrm{~b}$ & $11.56 \pm 0.34 \mathrm{ab}$ & $46.89 \pm 0.77$ \\
P24 & $87.44 \pm 2.21 \mathrm{a}$ & $12.22 \pm 0.46 \mathrm{a}$ & $47.56 \pm 0.67$ \\
P32 & $83.67 \pm 1.08 \mathrm{a}$ & $12.56 \pm 0.29 \mathrm{a}$ & $48.56 \pm 0.84$ \\
P40 & $84.89 \pm 1.44 \mathrm{a}$ & $10.78 \pm 0.28 \mathrm{~b}$ & 5.05 \\
\% CV & 8.74 & 10.37 & $15.19^{*}$ \\
$F_{\text {IL }}$ & $26.32^{* *}$ & $25.90^{* *}$ & $2.02^{\mathrm{ns}}$ \\
F F $_{\text {F }}$ & $41.04^{* * *}$ & $9.524^{* * *}$ & $0.40^{\mathrm{ns}}$ \\
\hline
\end{tabular}

Positive effects of both different irrigation levels and phosphorus levels were observed in terms of plant height (Table 1). When the effect of irrigation levels on plant height was examined, the highest value was achieved in irrigation conditions with full irrigation (IL100) with $85.75 \mathrm{~cm}$ and slight water restriction (IL66) with $82.83 \mathrm{~cm}$, while the lowest $(78.00 \mathrm{~cm})$ was obtained from plants with severe water restriction. As the water restriction increased, the plant height decreased (Table 1). It was reported that different irrigation levels were effective on average plant height in Adana [23] and Aydın conditions [24]. Moreover, the highest plant height was obtained from plants without water restriction [24]. When the effect of phosphorus applications on plant height was investigated, the highest value was recorded in P24 $(87.44 \mathrm{~cm})$, in addition P40 $(84.89 \mathrm{~cm})$ and P32 $(83.67 \mathrm{~cm})$ were included in the same statistical group. The shortest plants were measured in P16 $(72.78 \mathrm{~cm}$ ) application (Table 1). This result was consistent with the studies that report stunting [25], slowing growth and development [26] in plants in phosphorus deficiency.

Significant effects of different irrigation levels and phosphorus doses on leaf number were observed. When examined in terms of the effect of irrigation levels, the highest number of leaves was recorded in IL100 (12.42 per plant) and the lowest in IL33 (10.92 per plant) applications (Table 1). However, the number of leaves in full irrigation (IL100) and slight water restriction conditions (IL66) were in the same statistical group. When the effect of phosphorus levels was examined, the highest value was obtained from P32 (12.56 per plant) application, while the increase in phosphorus doses up to this point had an increasing effect in terms of leaf number. P32 and P24 did not show a statistically significant difference. The lowest number of leaves was found with 10.78 per plant in P40. Subsequently, the lowest value was obtained from P16 (11.56 per plant), that is the lowest phosphorus application. Consistent with previous studies, the number of leaves decreased in plants as a result of phosphorus deficiency [27, 28]. The effect of 
phosphorus levels applied to cotton on the number of leaves may vary depending on the genotype [28].

In terms of chlorophyll amount, only the effect of irrigation levels was found to be statistically significant. As the water shortage increased, the amount of chlorophyll decreased. There is an inverse proportion between the water shortage and the amount of chlorophyll. The highest amount of chlorophyll was found in full irrigation (49.17 cci), similarly in plant height and leaf number, while the lowest result (45.75 cci) was found under severe water restriction (IL33). The amount of chlorophyll increased linearly with irrigation. This result indicated that photosynthesis slows down in plants under drought stress and there is a decline in the transport of photosynthesis products. [29] found amount of chlorophyll 38.9-50.1 in cotton. [30] reported the same results. The increase in phosphorus levels had an increasing effect on the amount of chlorophyll, but this increase was found to be statistically insignificant. However, in plants with phosphorus deficiency, the amount of chlorophyll may increase in some conditions, and in phosphorus deficiency, the regression of chlorophyll production occurs earlier unlike most other nutrient deficiencies [31].

The effects of different irrigation levels and phosphorus application on fresh weight and dry weight in cotton were given in Table 2. The fresh weight values of cotton at different irrigation levels were divided into three groups, while dry weight values were the lowest at the severe water restriction level, and the highest at the slight water restriction and the full irrigation level. This situation showed that the slight water restriction does not cause a significant decrease in dry weight. In terms of phosphorus levels, it was observed that fresh and dry weight values increased up to P24 level and then decreased.

Table 2. Mean values for fresh weight and dry weight at different irrigation and phosphorus levels

\begin{tabular}{lcc}
\hline Irrigation Levels & $\begin{array}{c}\text { Fresh Weight } \\
(\mathrm{g})\end{array}$ & $\begin{array}{c}\text { Dry Weight } \\
(\mathrm{g})\end{array}$ \\
\hline IL 33 & $35.55 \pm 3.16 \mathrm{c}$ & $23.51 \pm 0.91 \mathrm{~b}$ \\
IL 66 & $41.13 \pm 1.63 \mathrm{~b}$ & $25.49 \pm 0.48 \mathrm{a}$ \\
IL 100 & $48.49 \pm 1.69 \mathrm{a}$ & $25.78 \pm 0.52 \mathrm{a}$ \\
\hline P Levels & & \\
\hline P16 & $34.11 \pm 2.19 \mathrm{c}$ & $23.71 \pm 0.66 \mathrm{~b}$ \\
P24 & $48.62 \pm 2.06 \mathrm{a}$ & $26.73 \pm 0.68 \mathrm{a}$ \\
P32 & $42.97 \pm 2.53 \mathrm{ab}$ & $25.79 \pm 0.77 \mathrm{a}$ \\
P40 & $41.19 \pm 3.69 \mathrm{~b}$ & $23.47 \pm 0.71 \mathrm{~b}$ \\
\hline \% CV & 22.40 & 9.86 \\
F IL $_{\text {F }}^{*}$ & $50.85^{* *}$ & $11.86^{*}$ \\
F $_{\text {IL } x}$ P & $12.90^{* * *}$ & $9.44^{* * *}$ \\
\hline
\end{tabular}

The effects of phosphorus applications at different irrigation levels on fresh weight and dry weight were found to be statistically significant (Table 3).

Table 3. Interaction of irrigation and phosphorus levels on fresh weight and dry weight

\begin{tabular}{|c|c|c|c|c|c|c|}
\hline & \multicolumn{6}{|c|}{ Irrigation Levels (\%) } \\
\hline & & & IL33 & IL66 & IL100 & P Levels Avg $\pm \mathrm{SE}$ \\
\hline \multirow{5}{*}{ 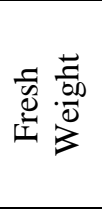 } & \multirow{4}{*}{ P Levels ( $\mathrm{mg} \mathrm{kg}^{-1}$ ) } & P16 & $28.27 \pm 1.39 \mathrm{Cc}$ & $32.57 \pm 0.42 \mathrm{Bb}$ & $41.50 \pm 3.13 \mathrm{Ab}$ & $34.11 \pm 2.19$ \\
\hline & & $\mathrm{P} 24$ & $51.00 \pm 5.47 \mathrm{Aa}$ & $44.77 \pm 1.88 \mathrm{Ba}$ & $50.10 \pm 2.48 \mathrm{Aa}$ & $48.62 \pm 2.06$ \\
\hline & & P32 & $34.70 \pm 3.40 \mathrm{Cb}$ & $43.73 \pm 1.12 \mathrm{Ba}$ & $50.47 \pm 1.13 \mathrm{Aa}$ & $42.97 \pm 2.53$ \\
\hline & & $\mathrm{P} 40$ & $28.22 \pm 1.78 \mathrm{Cc}$ & $43.47 \pm 2.02 \mathrm{Ba}$ & $51.90 \pm 3.49 \mathrm{Aa}$ & $41.19 \pm 3.69$ \\
\hline & IL $\mathrm{Avg} \pm \mathrm{SE}$ & & $35.55 \pm 3.16$ & $41.13 \pm 1.63$ & $48.49 \pm 1.69$ & \\
\hline \multirow{5}{*}{$\begin{array}{l}\overrightarrow{0} \\
\frac{000}{0} \\
\overrightarrow{3} \\
\vec{D} \\
\vec{D}\end{array}$} & \multirow{4}{*}{ P Levels ( $\mathrm{mg} \mathrm{kg}^{-1}$ ) } & P16 & $21.97 \pm 0.68 \mathrm{Bc}$ & $23.17 \pm 0.38 \mathrm{Bb}$ & $26.00 \pm 0.53 \mathrm{Ab}$ & $23.71 \pm 0.66$ \\
\hline & & $\mathrm{P} 24$ & $27.40 \pm 1.74 \mathrm{Aa}$ & $27.20 \pm 0.65 \mathrm{Aa}$ & $25.60 \pm 1.04 \mathrm{Bb}$ & $26.73 \pm 0.68$ \\
\hline & & P32 & $23.60 \pm 1.54 \mathrm{Cb}$ & $25.90 \pm 0.36 \mathrm{Ba}$ & $27.87 \pm 0.18 \mathrm{Aa}$ & $25.79 \pm 0.77$ \\
\hline & & $\mathrm{P} 40$ & $21.07 \pm 0.69 \mathrm{Cc}$ & $25.67 \pm 0.45 \mathrm{Aa}$ & $23.67 \pm 0.26 \mathrm{Bc}$ & $23.47 \pm 0.71$ \\
\hline & IL $\operatorname{Avg} \pm S E$ & & $23.51 \pm 0.91$ & $25.49 \pm 0.48$ & $25.78 \pm 0.52$ & \\
\hline
\end{tabular}

Capital letters represent irrigation levels for each dose of phosphorus, lowercase letters represent phosphorus doses for each irrigation level. While the highest fresh weight value was determined at P24 phosphorus level in severe water restriction, it was observed that fresh weights decreased in other high dose phosphorus applications (P32 and P40). Also under slight water restriction conditions, the highest fresh weight was detected at the P24 dose, but the downward trend after this dose was observed to be less than in severe water restriction conditions. Under full irrigation conditions, at higher doses compared to P16 dose, there was a linear increase in fresh weight, albeit slightly, with the increase in phosphorus dose (Figure 1). The same situation appeared in terms of dry weight, although it was not obvious. This results indicated that irrigation levels were effective in phosphorus intake. This effect may also vary depending on the genotype [28]. 


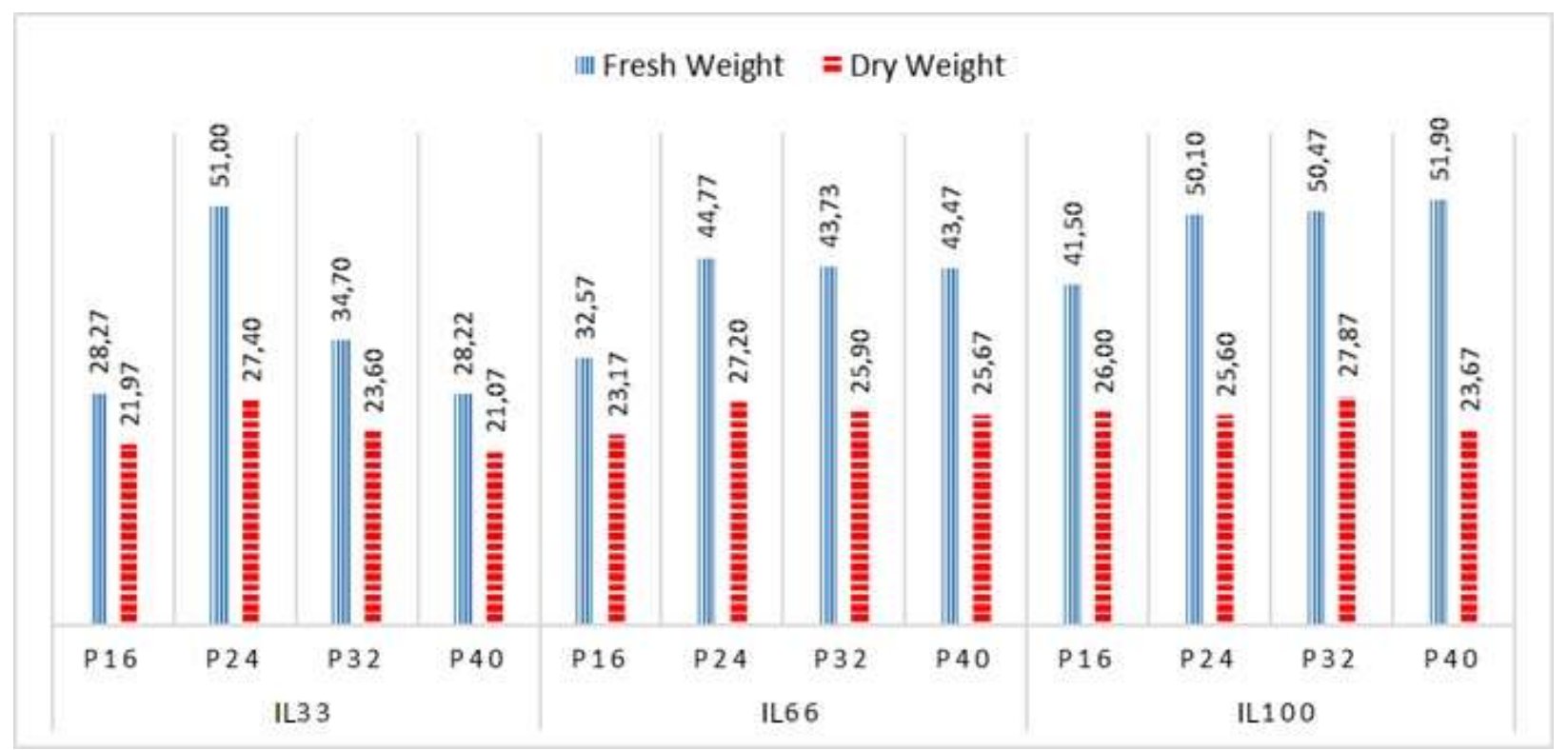

Figure 1. Effects of phosphorus applications at different irrigation levels on fresh weight and dry weight

\section{Conclusion and discussion}

In this research which the effects of different phosphorus doses on cotton growth under full and restricted irrigation conditions, it has been observed that irrigation levels had statistically significant effects on plant height, leaf number, chlorophyll amount, fresh weight and dry weight. On the other hand, phosphorus doses had an effect on parameters other than chlorophyll content, while the interaction of the two factors in terms of dry weight and fresh weight was found to be statistically significant.

In terms of plant height, number of leaves and chlorophyll amount, the values obtained when $66 \%$ of the plant water need was met, showed statistically similarity with the results obtained under full irrigation conditions. When the irrigation level was reduced to $33 \%$, the values obtained from these parameters, contained a significant difference considering other irrigation levels. Decrease in the water amount of the soil reduces the efficiency of phosphorus use [26].

While P16 application gave the lowest plant height result, a difference among the phosphorus doses higher than P16 was not detected. The lowest result in terms of the number of leaves was achieved in the P40 application.

It has been clearly demonstrated that cotton is highly sensitive to water stress and phosphorus doses up to boll formation. It has been reported that cotton is susceptible to water stress before flowering [32] and during the boll formation period [33]. However, according to [33], the effects of this stress vary according to the genotype of the plant.

When all these results were evaluated, determination and development of cultivars that are tolerant to water restriction in cotton, especially in early phenological periods; it is deemed necessary to carry out researches in order to reduce drought stress in plants in a sustainable way in limited irrigation conditions.

It should be taken into consideration that the results may represent similar soil and climatic conditions, because the research was conducted in greenhouse conditions with the soil taken from Amik Plain and Flash cotton cultivar.

\section{Acknowledgment}

This study was supported by the Hatay Mustafa Kemal University Coordinatorship of Scientific Research Projects with the project number 1105 Y 0137.

\section{References}

[1] Mert, M. (2020). Lif Bitkileri. NOBEL Yayınları No: 1734, Üçüncü Baskı. Ankara.

[2] Mert, M. (2011). Pamuk Tarımının Temelleri, TMMOB Ziraat Mühendisleri Odası, Teknik Yayınlar Dizisi, No:7, İkinci Bask1, Hatay.

[3] Ertekin, İ., Yılmaz, Ş., Atak, M., Can, E., Çeliktaş, N. (2017). Tuz Stresinin Bazı Yaygın Fiğ (Vicia sativa L.) Çeşitlerinin Çimlenmesi Üzerine Etkileri. Mustafa Kemal Üniversitesi Ziraat Fakültesi Dergisi, 22(2), 10-18.

[4] Ertekin, İ., Yılmaz, Ş., Atak, M., Can, E. (2018). Effects of Different Salt Concentrations on the Germination Properties of Hungarian Vetch (Vicia pannonica Crantz.) Cultivars. Turkish Journal of Agricultural and Natural Science, 5(2), 175-179.

[5] Ertekin, İ., Atış, İ., Yılmaz, Ş. (2020). Bazı fiğ türlerinin yem verim ve kalitesi üzerine farklı organik gübrelerin 
etkileri. Mustafa Kemal Üniversitesi Tarım Bilimleri Dergisi, 25(2), 243-255.

[6] Aygün, Y.Z., Mert, M. (2020). Toprak düzenleyicileri ve azot uygulamalarının pamukta (Gossypium hirsutum L.) verim ve lif teknolojik özelliklere etkisi. Biyolojik Çeşitlilik ve Koruma, 13 (3) , 290-297.

[7] Tekinel, O., Kanber, R. (1989). Pamuk Sulamasının Genel İlkeleri. Ç.Ü. Zir. Fak. Yardımcı Ders Kitapları Yay. No: 18, Adana.

[8] Günel, E., Mert, M. (1998). Pamuk Tarımında Kuraklığa Karşı Alınması Gereken Önlemler ve Kuraklığa Karşı Dayanıklı Pamuk Çeşitlerinin Geliştirilmesi, Mustafa Kemal Üniversitesi Ziraat Fakültesi Dergisi, 3(1), 99-114.

[9] Tekinel, O., Kanber, R. (1979). Çukurova Koşullarında Kısıntılı Su Kullanma Durumunda Pamuğun Su Tüketimi ve Verimi. Tarsus Bölge Topraksu Araştırma Enstitüsü Yayın no:98, rapor no: 48, Tarsus.

[10] Şahin, A., Ekşi, I., Kıvılcım, M.N., Özbek, N. (2000). Melezleme Islahı ile Kuraklığa Dayanıklı pamuk Çeşitlerinin Geliştirilmesi. Nazilli Pamuk Araştırma Enstitüsü Müd. Yayın no: 56, Nazilli.

[11] Yar, A., Iqbal, M.S., Ali, A., Akram, H.M., Saeed, M., Sahi, K.A. (2003). Optimum Time of Last Irrigation for Cotton Cultivars FH-634 and CIM-443. Asian Journal of Plant Sciences, 2(4), 365-367.

[12] Shah, S.H., Kiani, M.S., Malik, M.A. (1999). Growth and Yield Response of Two Cotton Cultivars to Irrigation Frequency. J Agri and Plant Sci, 9: 61-64.

[13] Aygün, C., Kara, İ., Sever, A.L., Erdoğdu, İ., Atalay, A.K., Özaydın, K.A., ... \& Bozkurt, M. (2017). Eskişehir İli Meralarının Azotlu ve Fosforlu Gübre Gereksinimlerinin Belirlenmesi. Toprak Su Dergisi, 6(1), 44-51.

[14] Ertekin, E.N., Ertekin, İ., Bilgen, M. (2020). Effects of Some Heavy Metals on Germination and Seedling Growth of Sorghum. KSU Journal of Agriculture and Nature, 23(6), 1608-1615.

[15] Yücel, E., Edirnelioğlu, E., Soydam, S., Çelik, S., \& Çolak, G. (2009). Porsuk çayında ağır metal kirlilik düzeylerinin Myriophyllum spicatum Başaklı Sucivanperçemi bitkisi ile biyomonitörlenmesi. Biyolojik Çeşitlilik ve Koruma, 3(2), 133-144.

[16] Russell, E.W. (1973). Soil Condition and Plant Growth. The English Language Book Society and Longman, London.

[17] Ektiren, Y,. Değirmenci, H. (2018). Kısıntılı Sulama Uygulamalarının Pamukta (Gossypium hirsutum L.) Yaprak Bitki Besin Elementlerine Etkisi. KSÜ Tarım ve Doğa Derg, 21(5), 691-698.

[18] Anonymous. (2021). ProGen Seed. https://www.progenseed.com/progen/20/cotton-seed-flash.html (Date of access 11.08.2021).

[19] Hake, S.J., Grimes, D.W., Hake, K.D., Kerbay, T.A., Munier, D.J., Zelinski, L.J. (1996). Irrigation scheduling. In Hake SJ, Kerbay TA and Hake KD (eds.) Cotton production manual. P. 228-247. University of California, Division of Agriculture and Natural Resources, Publication, 3352.

[20] Kılıç, Ş., Ağca, N., Karanlık, S., Şenol, S., Aydın, M., Yalçın, M., ... Çullu, M.A. (2008). “Amik Ovasının Detaylı Toprak Etütleri, Verimlilik Çalışması ve Arazi Kullanım Planlaması” Devlet Planlama Teşkilatı (DPT) Projesi, Proje no: DPT2002K120480, Hatay.

[21] IBM Corp. Released. (2016). IBM SPSS Statistics for Windows, Version 24.0. Armonk, NY: IBM Corp.

[22] Tukey, J.W. (1953). The Problem of Multiple Comparisons. Unpublished Manuscript, Princeton University, Princeton, NJ.

[23] Kaçar, M.M. (2007). Farklı Su ve Gübre Sistemlerinin Pamuk Bitkisinde Su Stres İndeksinin Değişiminin İncelenmesi. Çukurova Üniversitesi Fen Bilimleri Enstitüsü Tarımsa Yapılar Ve Sulama Anabilim Dalı, Yüksek Lisans Tezi, 45 sy.

[24] Dağdelen, N., Sezgin, F., Gürbüz, T., Yılmaz, E., Akçay, S. (2009). Farklı Sulama Aralığı ve Sulama Düzeylerinin Pamukta Bazı Verim Özellikleri ve Lif Kalitesi Üzerine Etkisi. ADÜ Ziraat Fakültesi Dergisi, 6(1), 53-61.

[25] Özen, H.Ç., Onay, A. (2013). Bitki Fizyolojisi. Nobel Yayınları No:578. İkinci Baskı, Ankara.

[26] Kaçar, B. (2020). Sürdürülebilir Tarımda İnsanda ve Hayvanlarda Fosfor, NOBEL Yayınları No: 2588, 1. Baskı, Ankara.

[27] Lynch, J., Lauchli, A., Epstein, E. (1991). Vegetative Growth of the Common Bean in Response to Phosphorus Nutrition. Crop Sci, 31, 380-387.

[28] Iqbal, A., Gui, H., Zhang, H., Wang, X., Pang, N., Dong, Q., ... Song, M. (2019). Genotypic Variation in Cotton Genotypes for Phosphorus-Use Efficiency. Agronomy, 9(11), 689.

[29] Yazdıç, M., Değirmenci, H. (2018). Pamukta Farklı Sulama Seviyelerinin Yaprak Su Potansiyeli ve Klorofil Değerine Etkisi. KSÜ Tarım ve Doğa Derg, 21(4), 511-519

[30] Brevedan, E.R., Hodges, H.F. (1973). Effects of Moisture Deficits on 14C Translocation in Corn (Zea mays L.). Plant Physiology, 52(5), 436-439.

[31] Rao, I.M., Terry, N. (1989). Leaf Phosphate Status, Photosynthesis, and Carbon Partitioning in Sugar Beet. I. Changes in Growth, Gas Exchange, and Calvin Cycle Enzymes. Plant Physiol, 90, 814-819.

[32] Loka, D.A. (2012). Effect of Water-Deficit Stress on Cotton During Reproductive Development. PhD Thesis, University of Arkansas, Fayetteville.

[33] Loka, D.A., Oosterhuis, D. (2012). Water Stress and Reproductive Development in Cotton. Department of Crop, Soil, and Environmental Sciences University of Arkansas, Fayetteville, AR 72704, Chapter 5. 